北関東医学

30 ( 2) : 19 23, 1980

肺癌の胸部大動脈への癒着を思わせる

気管支動脈造影所見について

$\begin{array}{llllll}\text { 早 川 和 重, 松 本 満 臣, 岡 崎 篤, } \\ \text { 境 野 宏 治, 清 水 幸 夫, } \text {, 福 田 敬 宏, }^{* *} \\ \text { 馬 場 } & \text { 孝** } & & & & \end{array}$

群馬県立がんセンター東毛病院放射線診療部*, 胸部診療部 ${ }^{* *}$ (院長 : 三輪 潔博士)

(昭和55年 4 月 8 日 受付)

I は じめに

気管支動脈造影（以下 BAG と略す）は肺癌の診 断上不可欠のものとはいえないが，抗がん剤の one shot 動注などを目的として施行される場合の意義 は大きい1).

われわれは過去約100例以上に BAG を施行し，そ の一部については既に報告した が，その中で肺癌 の原発巣，または転移巣が直接大動脈に癒着してい ると思われる所見を呈した 2 例を経験したのでここ に報告する。

\section{II 症例}

症例1. K. O. ( No25119) 47才 男性. 未分化腺癌

昭和 52 年 9 月検診にて胸部単純 $X$ 線写真上異常陰
影を指摘された。自覚症状はない。初診時の胸部単 純写真（第1図A）では，左上葉舌区に比較的円形 であるが不整縁を有する腫瘍影があり，中にいくつ かの小透亮像がみられる。また，左肺門にリンパ節 腫大がみられ, さらに縦隔影上部両側にも縦隔のシ ルエットから突出した㓌影がみられ，肺門および縦 隔リンバ節への転移を強く疑わせる。ゼロトモグラ 厶（第 1 図B）では左傍気管透亮像が消失し,この 部分の濃度が一様となり, これはいわゆるボタロー のリンパ節，左気管気管支リンパ節への転移を強く 疑わせる所見である ${ }^{3(2)}$. すなわち単純写真の所見 と合わせ，大動脈弓リンパ節，右気管気管支リンパ 節，左傍気管リンパ節，左気管気管支リンパ節への 転移と診断しうる。

左気管支動脈造影（第2図）では左肺舌区の腫瘍 内血管新生像とその中央への集束像およびそこから
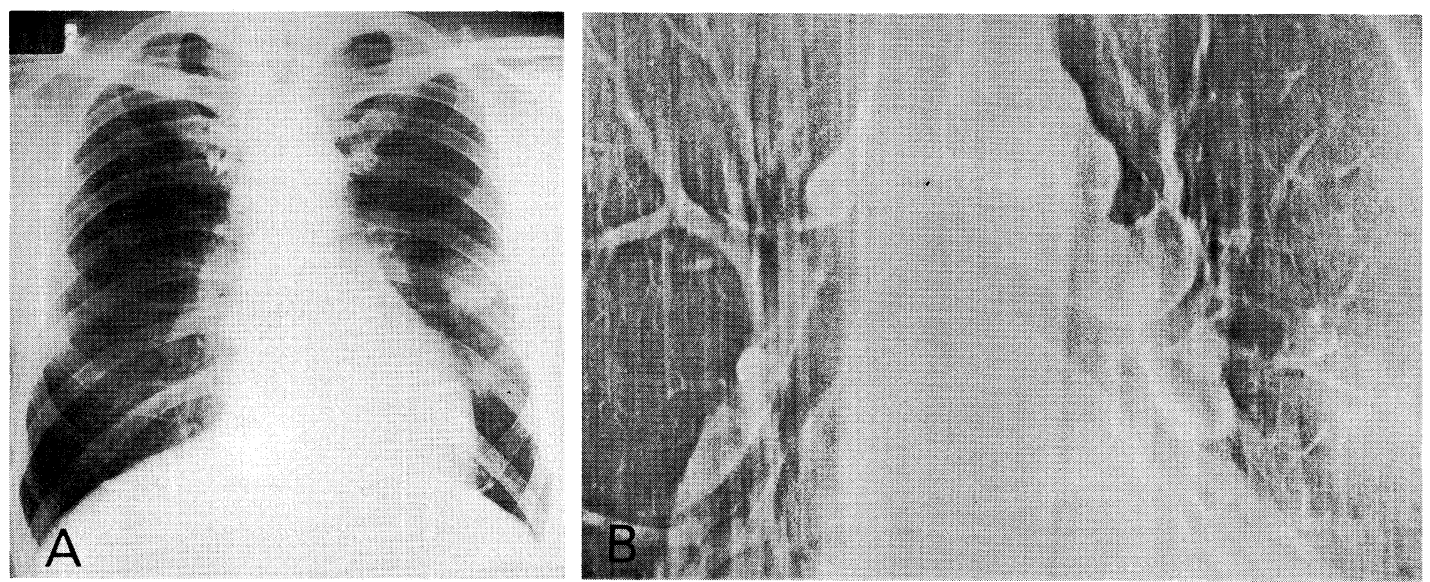

第 1 図症例 147 才男性, 未分化腺癌

A. 胸部正面像, 左肺舌区の腫瘍と肺門・縦隔リンパ節転移。

B. ゼロトモグラム, 左傍気管透亮像の消失があり, 左傍気管リンパ節, 左気管気管支リンパ節転 移は明らか。 


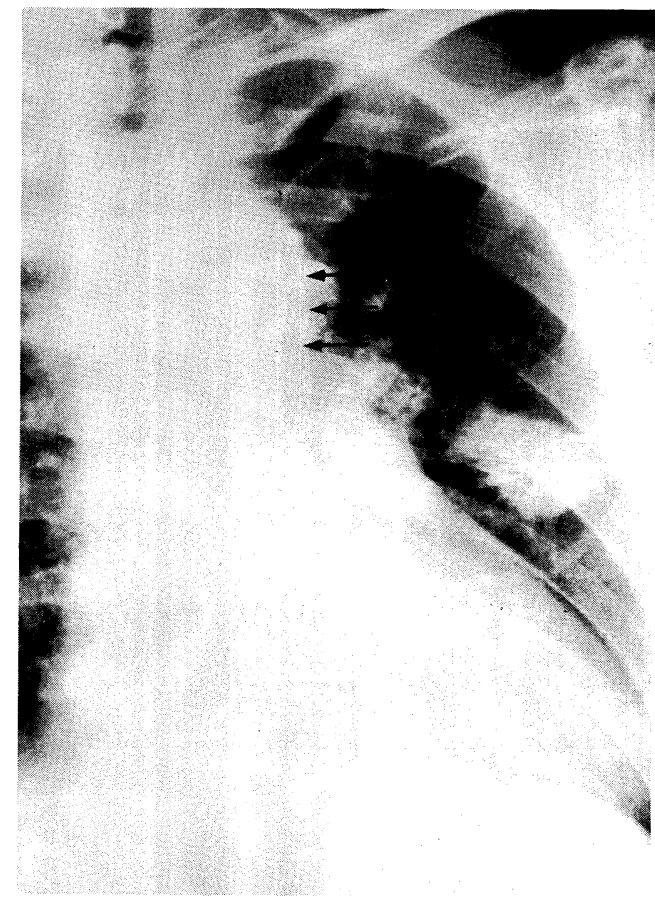

第 2 図症例 1 気管支動脈造影

原発巣, リンパ節の濃染像のほかに, 大動脈 外側縁に沿った血管新生像と, 大動脈を前後 からとり囲む血管新生像がみられる。

の周辺部への放散像がみられる.この所見はわれわれ の分類 I 型 21 に属するもので腺癌に特徵的と思われ る所見である。また肺門部には 3 個のリンパ節転移 が一部に血管の encasement を有する明瞭な Tumor stain としてみられる.さらに下行大動脈外側壁 に沿った明らかな血管新生像と，これに垂直に大動 脈を前後からとり囲むような新生血管が認められ る.

この例は，気管支動脈造影時にMMC $10^{\mathrm{m} g}$ の 動注 を行ったが，手術時には広汎な縦隔リンパ節への転 移があり, 転移巣の一部は胸部大動脈と癒着し用指 剝離が困難であると思われる進展が認められたため リンパ節の試験切除のみに終わっている，組織型は 低分化腺癌であった。

\section{症例2. C.T.(№.32252) 69才 男性. 扁平上皮癌}

昭和54年 3 月頃から時々血痰が出るために来院し た. 初診時の胸部単純写真正面像（第 3 困A）では

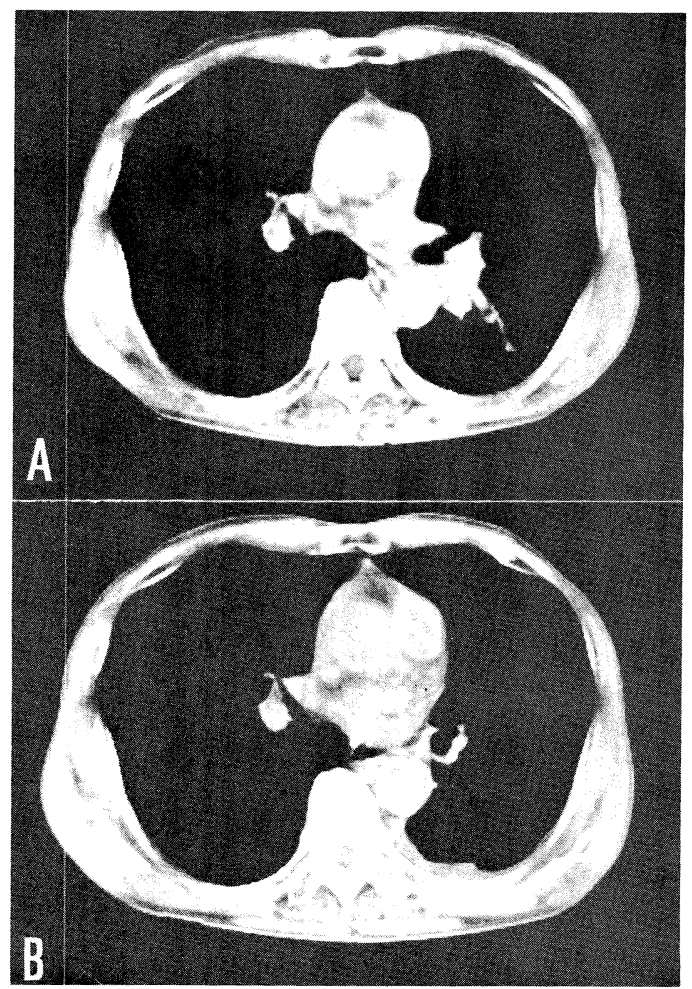

第 4 図 症例 2 C Tスキャン

A. $\mathrm{S}_{6}$ の不整形の腫痬があり, 下行大動脈と接し ている。

B. 放射線治療後には腫瘍影は消失し, 大動脈の 輪郭が明らかとなった。

左肺門近くに不均等な淡い院影がみられる。側面像 では $\mathrm{S}_{6}$ の部位に一致してやはり濃度の高い㓌影が 認められる。側面断層像 (第 3 図B) では $\mathrm{S}_{6}$ の部位 に下気管支幹内腔に突出した部分をもつ腫瘍影が認 められ， $\mathrm{B}_{6}$ の閉塞と下気管支幹の狭窄が認められ る。

気管支造影（第 3 図C）では $B_{6}$ は全く描出され ず，断層像でみられた下気管支幹の狭窄が認められ る.

次に気管支動脈造影の前日に行われた CT スキャ ン（第 4 図A）では，ウインドウレベル，ウインド ウ巾をどのように選択しても腫瘍影と大動脈影との 境界は不明瞭であった。

気管支動脈造影（第 3 図 D ）では，腫瘍内にほぼ 均等に血管新生像があり,下葉気管支に沿った血管 の encasement がみられる。これはわれわれの分類 

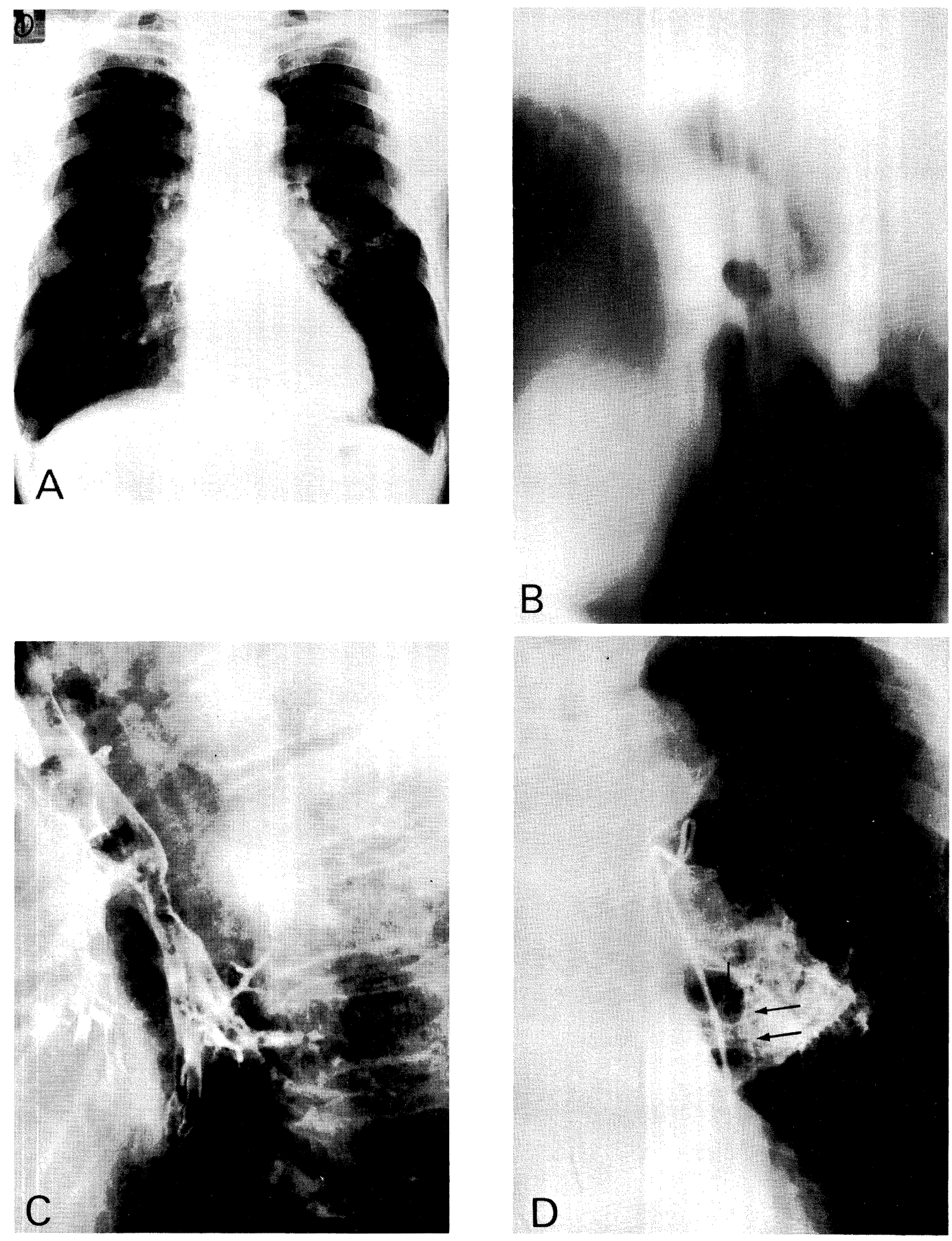

第 3 図症例 269 才男性, 扁平上皮癌

A. 胸部正面像, 左肺門部の軽度の濃度の増強がある。

B. 左肺側面断層, 上幹の分岐の直下の下幹の狭窄と $\mathrm{B}_{6}$ の閉塞, および $\mathrm{S}_{6}$ の腫瘍影がみられる。

C. 気管支造影, $\mathrm{B}_{6}$ の閉塞と下幹の狭窄が明らか.

D. 気管支動脈造影，下行大動脈外側縁に沿う血管新生と大動脈をとり囲む血管新生像がみられる. 
II 型 ${ }^{2)}$ に属する所見で，扁平上皮癌にみられること が多い。この例においても症例 1 と同様に大動脈外 側壁に沿った細血管の新生像とこれに垂直な大動脈 をとり囲むような血管新生像とが見られた。なお本 症例は肺機能が悪く手術は行われていない.

放射線治療後の CT スキャンでは第 4 図Bのごと く, 腫瘍は縮小して下行大動脈の左壁は辺縁平滑と なった。

$$
\text { III 考按 }
$$

Viamonte $^{7)}$ が選択的気管支動脈造影を報告して 以来, 種々の観点から BAG 像の解析がなされて来 た。肺癌においては最近では抗がん剂の one shot 動 注などの目的で施行される本法の意義は大きく" また縦隔へのリンパ節転移を本法のみで知りえた症 例も報告されている6).しかし癒着であれ，浸潤であ れ, 肺癌の周囲臓器, 特に胸部大動脈への進展を示 唆する所見を述べている報告は現在までの文献検索 では見当らなかった。

症例 1, 2 とも(1)大動脈外壁に沿った血管新生像, (2)大動脈を前後からとり囲むような血管新生像とが 認められ，症例 1 では手術時に縦隔リンパ節転移巣 の大動脈への進展が強く大動脈からの用指剝離が困 難であった。症例 2 においては手術による確認はな いが症例 1 と同所見であることから肺癌の下行大動 脈への癒着の可能性が高い.

CTスキャンでは同程度の X 線吸収を有する組織 や臟器が接しているだけでその境界は消失すること もあるので断定的ではないが，腫瘍と大動脈との境 界が消失している時には腫瘍の大動脈への癒着を伴 う可能性は残る。また CT スキャン上，腫瘍影と胸 膜影との間でその境界が如何なる条件でも明瞭とな らない場合には腫瘍の胸膜への浸潤が考之られると いう報告もあり ${ }^{8)}$ ，上記の症例 2 におけるCT スキャ ン上の所見も $\mathrm{BAG}$ の所見と一致するものと思われ る。またこの進展が物理的には用指剝離困難であっ ても, 単なる胸部大動脈外膜への強い癒着なのか, あるいは顕微鏡的にも大動脈外壁への腫痬性浸潤が あるのか否かは今後更に検討されなければならな い.

しかし，小さな腫瘍であっても BAG 所見で上記 のような所見が得られたら抗がん剂の one shot 注 入や術前照射の適応になると考えられる。

\section{IV 結 論}

肺癌の原発巣あるいは転移巣の胸部大動脈への癒 着を示すと思われる気管支動脈造影所見を呈した 2 例を報告した。

その BAG 所見は

1）大動脈外壁に沿った長軸性の血管新生像

2）大動脈を前後からとり囲むような血管新生像 であった。

なお本稿の要旨は第302回日本医学放射線学会関東地方会に おいて報告した。御校閲をいただいた群馬大学医学部放射線 医学教室, 永井輝夫教授に深謝致します.

\section{文献}

1）尾形利郎，他：外科的にみた肺がん化学療法の 問題点，一局所投与療法を中心に一，肺と心， $13: 316-324,1966$.

2）松本満臣，他：肺癌の気管支動脈造影，一組織 型およびリンパ節転移診断の可能性について 一, 北関東医学, $28: 137-144,1978$.

3）土屋了介, 他：Xerotomography の肺癌診断へ の応用, 映像情報, $9: 29-33,1977$.

4）土屋了介, 他：ゼロトモグラフィの肺疾患診断 への応用, 一肺癌の診断, 特に縦隔リンパ節腫 脹の読影について一, 日本胸部臨床, $37: 267$ $-274,1978$.

5）西脇裕：Xerotomogram に上る早期肺癌へのア プローチ（I ），臨床放射線, 24：645-650, 1979.

6）松本満臣, 他：Xerotomogram による早期肺癌 へのアプローチ（II ), 臨床放射線, 24：651-655, 1979.

7) Viamonte, M., Jr., et al : Guided catheterization of the bronchial arteries, Radiology, 85 : 205-229, 1965.

8）園山明, 他：肺癌診断への CT の応用, 肺癌, 第20回日本肺癌学会総会記事：63，1979. 


\title{
BRONCHIAL ANGIOGRAPHIC FINDINGS OF LUNG CANCER WITH ADHESION TO THE AORTIC WALL.
}

\section{KAZUSHIGE HAYAKAWA, MITSUOMI MATSUMOTO,* ATSUSHI OKAZAKI, ${ }^{*}$ KOHJI SAKAINO,* YUKIO SHIMIZU, ${ }^{* *}$ TAKAHIRO FUKUDA, ${ }^{* *}$ AND TAKASHI BABA**}

\author{
Department of Radiology* and Thoracic Surgery**, \\ Gunma Cancer Center Hospital. \\ (Directer : Dr. Kiyoshi Miwa)
}

Two cases of lung cancer in which the tumor adhesion to the aortic wall was considered on the bronchial angiogram are presented. In these cases, the bronchial angiographic(BAG) findings are as follows : (1)neovascularity along the outer margin of the aorta,(2)neovascularity crossing and encompassing the aorta.

In lst case, the mediastinal lymphadenopathy with adhesion to the aortic wall in which metastatic lymph nodes could not be torn off the aorta was surgically proven. In 2nd case, although not surgically proven, CT scan demonstrated no radiolucency between the primary lung tumor and the aortic wall. This CT finding is also considered to be equal to the above BAG findings. After completion of radiotherapy, CT revealed that lung mass was disappeared almost completely and that the aortic outline was normally rounded.

Key words : Lung Neoplasms, Angiography, Xeroradiography, X-ray Computed Tomography, Thoracic Aorta. 